\title{
Pb Removal from Contaminated Water Using EDTA with Colocasiaesculenta (L.) Schott at Klity Creek, Kanchanaburi, Thailand
}

\author{
${ }^{1,2,3}$ Pantawat Sampanpanish and ${ }^{4}$ Yotsavanun Hongpiriyakul \\ ${ }^{1}$ Environmental Research Institute, Chulalongkorn University (ERIC), Bangkok 10330, Thailand \\ ${ }^{2}$ Research Program of Toxic Substance Management in the Mining Industry, \\ Center of Excellence on Hazardous Substance Management (HSM), Bangkok 10330, Thailand \\ ${ }^{3}$ Research Unit of Green Mining Management (GMM), Chulalongkorn University, Bangkok 10330, Thailand \\ ${ }^{4}$ Interdisciplinary Program of Environmental Science, \\ Graduate School, Chulalongkorn University, Bangkok 10330, Thailand
}

Article history

Received: 16-04-2017

Revised: 25-09-2017

Accepted: 2-05-2018

Corresponding Author: Pantawat Sampanpanish, Environmental Research Institute, Chulalongkorn University (ERIC), Bangkok,10330, Thailand

Tel: $+662218-8219$

Fax: +662 218-8210

Email: pantawat.s@chula.ac.th

\begin{abstract}
This study investigated lead $(\mathrm{Pb})$ removal using a plant called'Elephant Ear' (Colocasiaesculenta (L.) Schott) from contaminated waterat Klity Creek, located in Kanchanaburi Province, Thailand. Plants weregrown in contaminated water with lead carbonate $\left(\mathrm{Pb}\left(\mathrm{CO}_{3}\right)_{2}\right)$ in a nursery. The experiment was divided into 4 sets; (1) With Pb but without EDTA, (2) With $\mathrm{Pb}$ and EDTA 0.01 millimole $(\mathrm{mM})$ per liter $\left(\mathrm{mM} \mathrm{L}^{-1}\right)$, (3) With Pband EDTA $0.02 \mathrm{mM} \mathrm{L}^{-1}$ and (4) With Pb and EDTA $0.03 \mathrm{mM}$ $\mathrm{L}^{-1}$. These plants were grown, maintained and harvested every $15,30,45$, 60, 75 and 90 days. Plant samples were separated into three parts; leaf, petiole and root. They were analyzed in terms of total lead $(\mathrm{TPb})$ content, including the water solution. The results showed that $\mathrm{Pb}$ accumulation in Elephant ear was relatively significant in all of the experiment sets $(\mathrm{p}<0.05)$ at 15 days. The results showed that $\mathrm{Pb}$ accumulation in the whole plant was highest at 90 days. This study showed that $\mathrm{Pb}$ absorption in plant was enhanced when the concentration of EDTA increased. Plants showed that $\mathrm{Pb}$ accumulation in roots $>$ petioles $>$ leaves were significant with $502.84,126.19$ and $91.06 \mathrm{mg} \mathrm{kg}^{-1}(\mathrm{p}<0.05)$ at EDTA of $0.02 \mathrm{mM}$ set, respectively. Plants exhibited signs of phytotoxicity, such as wilting and curling of their leaves, yellow color appearing in the leaf margins and the plants eventually dying. These effects could be used as an indicator for determining the presence of $\mathrm{Pb}$ in contaminated water and soil.
\end{abstract}

Keywords: Phytoremediation, Phytotoxicity, Lead, EDTA, Wastewater

\section{Introduction}

Lead $(\mathrm{Pb})$ is a heavy metal that is used in many industries, such as in the production of batteries and telephone cables; as a result, is widely mined around the world. Sludge and waste from industrial usage and mining are major causes of $\mathrm{Pb}$ contamination in soil and water. This inevitably has an impact on the ecosystem, vegetation, animals and health and sanitation of humans, as well as disrupting the food chain (Chen et al., 2006). Since 2006, mining activities in Thailand have created mine tailings, causing $\mathrm{Pb}$ contamination in sediment, which, specific to this study, has been naturally brought to Klity Creek in Kanchanaburi. Official authorities have tried to solve and alleviate this problem, but to date, there has been no success in remediation (Phenrat etal., 2016). At present, there are numerous remediation technologies being used to clean up heavy metal contamination in water, soil and sediment. These techniques include in situ physical and chemical processes (soil flushing, solidification and stabilization), thermal processes, ex situ physical and chemical processes (soil washing, chemical reduction and oxidation)and other processes including excavation and off-site disposal (Sampanpanish et al., 2006; Sampanpanish, 2015). Specifically, chemical and physical treatment techniques are considered to be potentially more cost effective than biological treatments 
(Tananonchai and Sampanpanish, 2014). It is worth noting that this treatment has been shown to be cost effective and environmentally friendly when using green plants or living organisms to clean up the contaminated sites called phytoremediation (USEPA 1998a; 1998b; 1999). Plants can be used for the uptake of heavy metals and translocate into the whole parts of the plant. Plants can accumulate heavy metals in their tissue, which might be a suitable treatment technique since this has a low cost and high performance in terms of successfully removing heavy metals (Aisien et al., 2012; Aransiola et al., 2013). A study by Tanhan (2008) showed a mechanism of phytoextraction using $\mathrm{Pb}$ as a remover from soil contaminated with Chromolaenaodorata. Whereas, $\mathrm{Pb}$, $\mathrm{Zn}$ and $\mathrm{Cd}$ treatment with Arabispaniculata was shown in a study by Tang et al. (2008). As recently as 2016, further research has shown how using a chelating agent also helps to increase the uptake of heavy metal in plants (Dumbrava et al., 2015). It is worth noting that Tambamroong (2002)studied the effects of EDTA to remove As (Arsenic) from contaminated soil with Taro and Elephant ear plants. Cho et al. (2008) studied $\mathrm{Pb}$ removal from contaminated soil using EDTA with green onions used for the uptake process. This research used Colocasiaesculenta to remediate $\mathrm{Pb}$ contaminated water from Klity Creek, Kanchanaburi province. $\mathrm{Pb}$ mining has been closed and not in operation for more than 20 years. Previously when in operation, impacts to the environment including the contamination of water, sediment and soil as well as impacts to the health of humans and animals. Therefore, this study investigated the ability of $C$. esculenta to be used for $\mathrm{Pb}$ uptake and translocation into plants from contaminated water and additive chelating agents.

\section{Materials and Methods}

\section{Water Preparation}

$\mathrm{Pb}$ as lead carbonate $\left(\mathrm{Pb}\left(\mathrm{CO}_{3}\right)_{2}\right)$ was dissolved in distilled water to prepare stock solutions at concentrations of $5 \mathrm{mg} \mathrm{L}^{-1}$.

\section{Pot Preparation}

Plastics black pots without holes were used, 45 centimeters in diameter and containing $20 \mathrm{~L}$ of tap water. The experiment was divided into 4 sets: (1) Pb solution without EDTA, (2) Pb solution with EDTA $0.01 \mathrm{mM}$ $\mathrm{L}^{-1}$, (3) Pb solution with EDTA $0.02 \mathrm{mM} \mathrm{L}^{-1}$ and(4) Pbsolution with EDTA $0.03 \mathrm{mM} \mathrm{L}^{-1}$. Each concentration was applied to 3 replications.

\section{Plant Preparation}

The plant selection used $C$. esculenta with lengths of between 15-20 centimeters and no traces of $\mathrm{Pb}$ were detectable prior to the study. Plant samples were maintained in a nursery for 30 days.

\section{EDTA Preparation}

EDTA concentrations were prepared by disodium salt of ethylenediaminetetraacetic acid at $0.01,0.02$ and 0.03 $\mathrm{mM} \mathrm{L}^{-1}$ and was added into a water solution of $5 \mathrm{mg} \mathrm{L}^{-1}$ $\mathrm{Pb}\left(\mathrm{CO}_{3}\right)_{2}$.

\section{Experimental Design}

Plant samples (C. esculenta) were excavated from uncontaminated soil and transferred to the hydroponic system (this included 6 plants per pot). Each pot had $\mathrm{Pb}$ carbonate solution added at a dose of $5 \mathrm{mg} \mathrm{L}^{-1}$ with $20 \mathrm{~L}$ of tap water. After 30 days, the EDTA concentrations were added. Each concentration of EDTA was applied to 3 replications. No chemical fertilizer or any other functional chemicals were used during the experiment.

\section{Water Analysis}

Water samples were collected at 15, 30, 45, 60, 75 and 90 day intervals during the cultivation. The total $\mathrm{Pb}$ $(\mathrm{TPb})$ in the water was analyzed with USEPA 3051 (USEPA, 1998) and analyzed by using Atomic Absorption Spectrometer (AAS).

\section{Plant Analysis}

Plant samples were harvested at 15, 30, 45, 60, 75 and 90 day intervals during the process of cultivation. Each time, samples were washed with tap water twice and rinsed with deionized water and air-dried at room temperature for 2-3 hours. These plants were separated into 3 parts: leaves, petiole and root and these were all measured in their wet-state. The plant was then dried in a hot-air oven at $105^{\circ} \mathrm{C}$ for $24-48 \mathrm{~h}$ until reaching a constant weight and then the leaves, petiole and root were all measured in their dry-state. Plant samples were digested by nitric acid, sulfuric acid and hydrogen peroxide with USEPA 3052 (USEPA, 1996). Pb was analyzed by Atomic Absorption Spectrometer (AAS).

\section{Phytotoxicity}

This study investigated the tolerance of $C$. esculentagrowing in $\mathrm{Pb}$ solution and determined the phytotoxicity due to the addition of EDTA. Plant's toxicity was observed in terms of the symptoms exhibited by the plants as a whole.

\section{Results and Discussion}

\section{pH in Water}

The water $\mathrm{pH}$ in all sets of the experiment ranged of 7.1-8.1 at 15-90 days, (Fig. 1a) which is the base level (Chiyapreuk, 1993). The water $\mathrm{pH}$ showed a trend of increasing as the experimental period increased. 


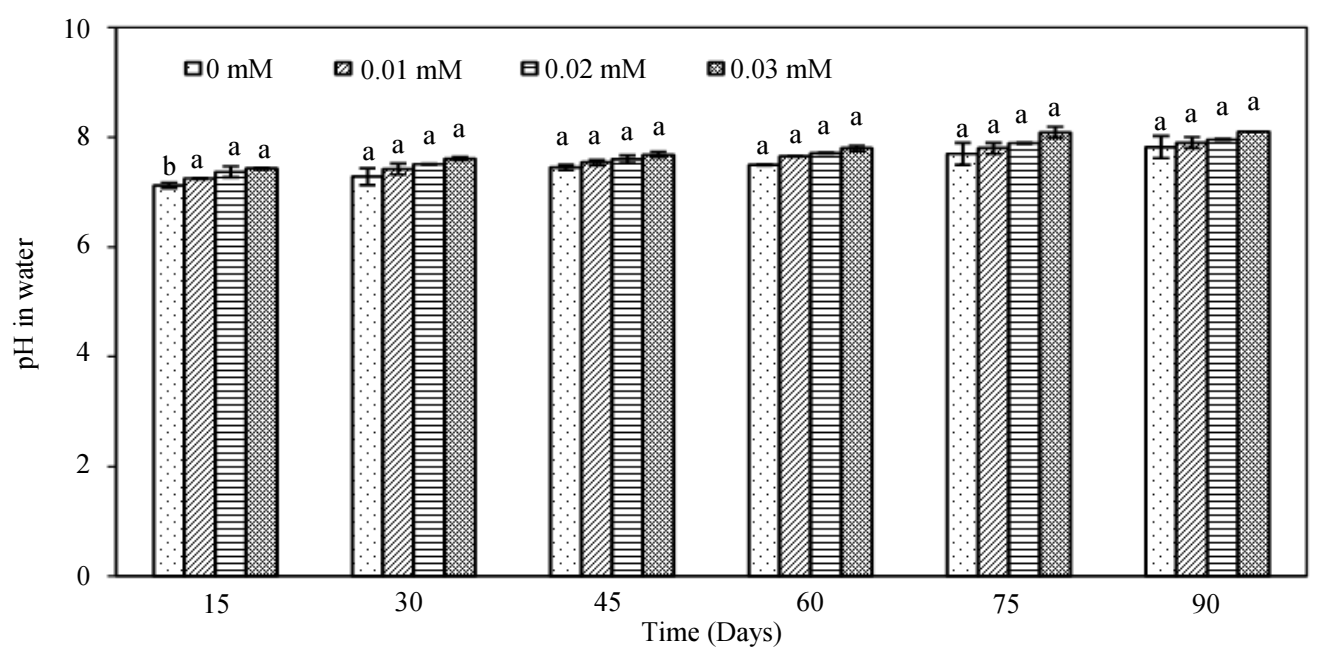

(a)

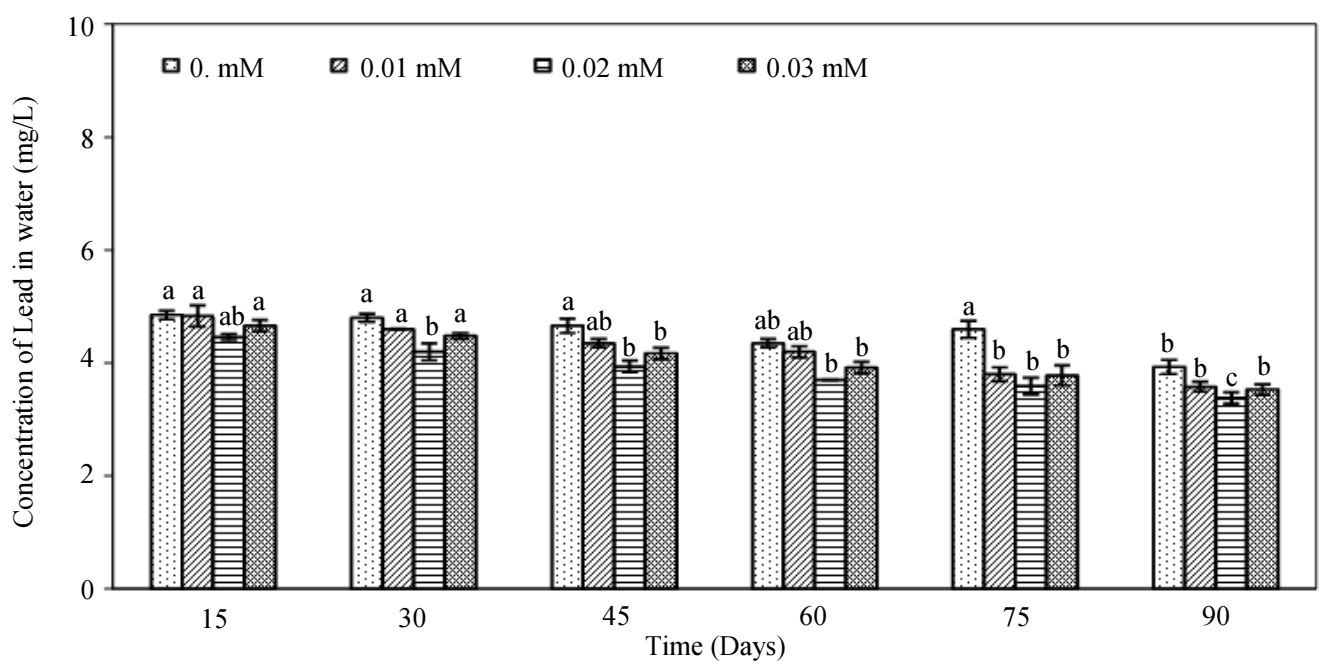

(b)

Fig. 1: (a) $\mathrm{pH}$ in contaminated water and (b) Concentration of $\mathrm{Pb}$ in contaminated water

\section{Pb Dose in Water}

Water samples showed the lowest $\mathrm{Pb}$ concentration of $4.47 \mathrm{mg} \mathrm{L}^{-1}$ at 15 days, (set of Pb solution with EDTA $0.02 \mathrm{mM} \mathrm{L}^{-1}$ ), which can be seen as a statistically significant difference between the sets $(\mathrm{p}<0.05)$ (Fig. 1b). For the set of $\mathrm{Pb}$ solution without EDTA, Pb solution with EDTA $0.01 \mathrm{mM} \mathrm{L}^{-1}$ and Pb solution with EDTA $0.03 \mathrm{mM}$ $\mathrm{L}^{-1}$ were $4.87,4.84$ and $4.67 \mathrm{mg} \mathrm{L}^{-1}$, respectively. These water solutions showed the highest $\mathrm{Pb}$ concentration and a trend that decreased when the experiment time increased and EDTA dose increased. The $\mathrm{Pb}$ concentration showed the lowest decrease of $3.41 \mathrm{mg} \mathrm{L}^{-1}$ at 90 days. Li et al. (2008) studied $\mathrm{Pb}$ uptake using EDTA concentrations of 0.1 and $0.5 \mathrm{mM} \quad \mathrm{L}^{-1}$ with Typhaorientalis. Their results showed that the Typhaorientalis absorbed $\mathrm{Pb}$ with the EDTA concentration at $0.1 \mathrm{mM} \mathrm{L}^{-1}$ higher than at $0.5 \mathrm{mM} \mathrm{L}^{-1}$, while EDTA concentration of $0.5 \mathrm{mM} \mathrm{L}^{-1}$ in a water solution was higher than the additive EDTA concentration $0.1 \mathrm{mM} \mathrm{L}{ }^{-1}$. However, Poopa et al. (2015) studied the sequential extraction method, which was employed to investigate the distribution and chemical fractions of $\mathrm{Pb}$ in Klity Creek sediments, Kanchanaburi, Thailand. The objective was to define the $\mathrm{Pb}$ mobility in sediment and potential bioavailability in relation to sediment contamination levels. The results showed that the background value of $\mathrm{TPb}$ concentration in the sediments from this area was higher than those reported from other locations in Thailand. Sequential extraction results revealed that $\mathrm{Pb}$ was mainly associated with the reducible fraction, especially in the polluted zone in the vicinity of the ore dressing plant (factory). 


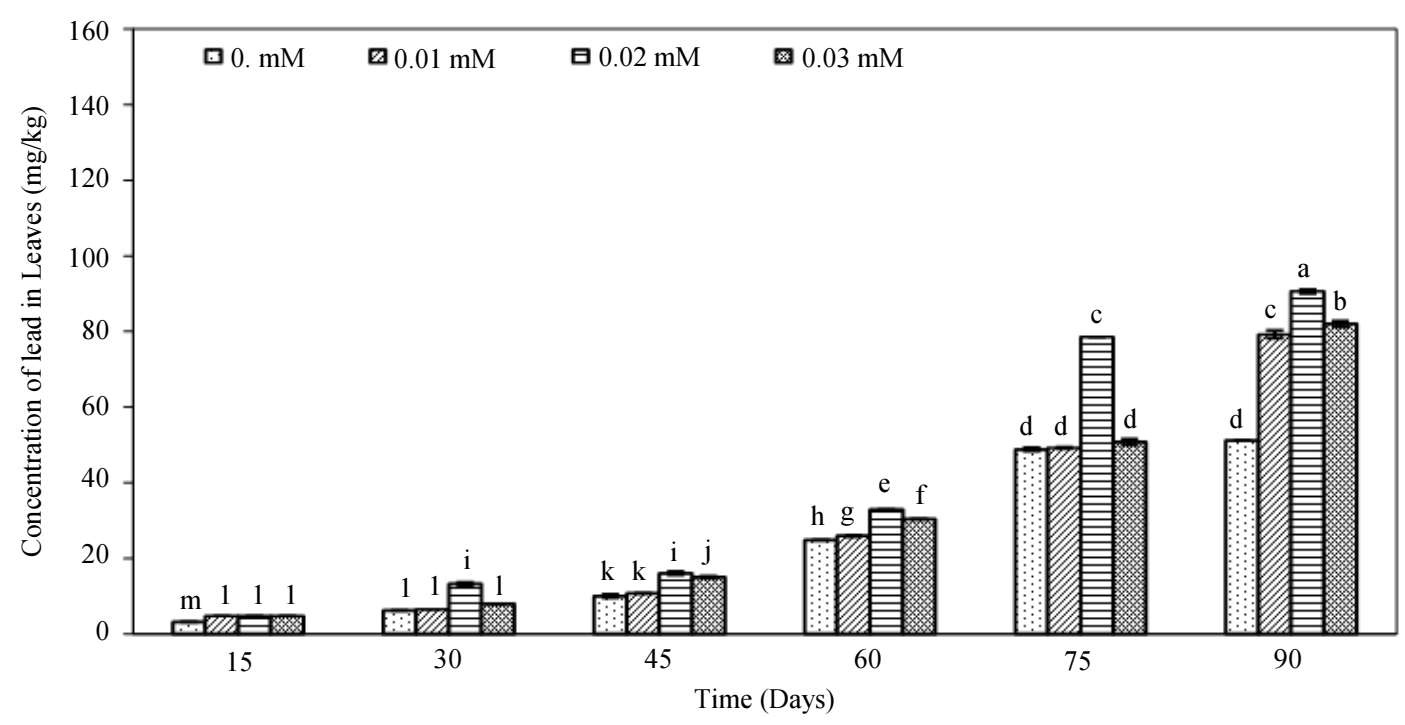

(a)

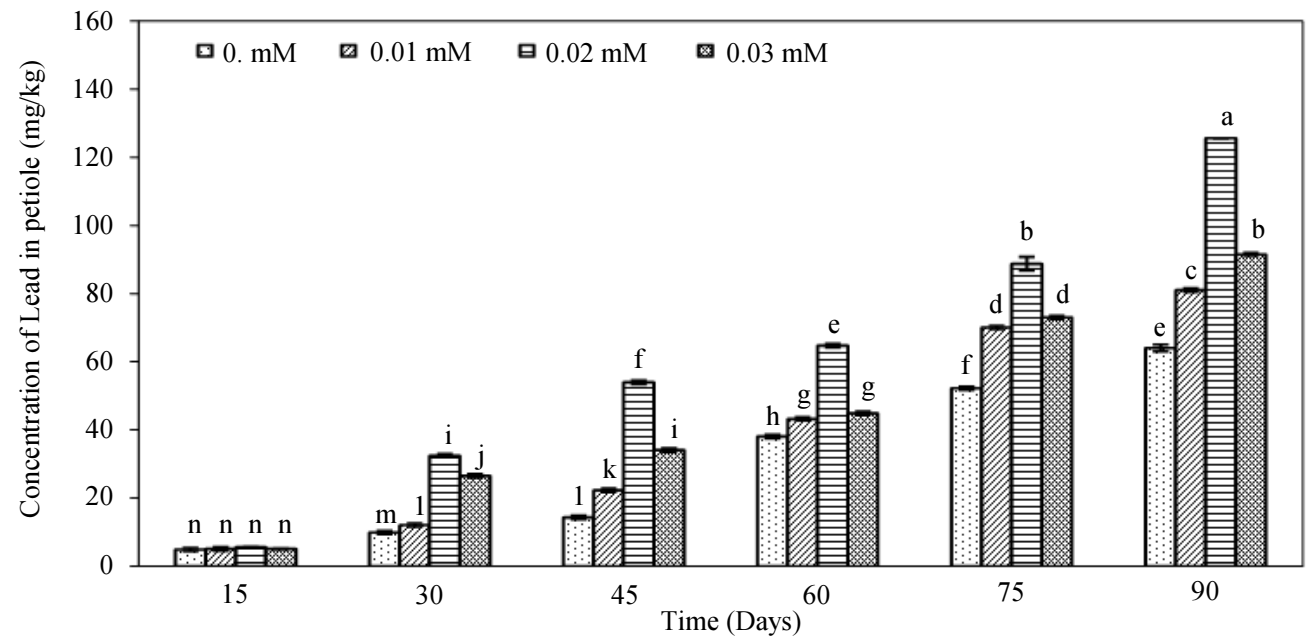

(b)

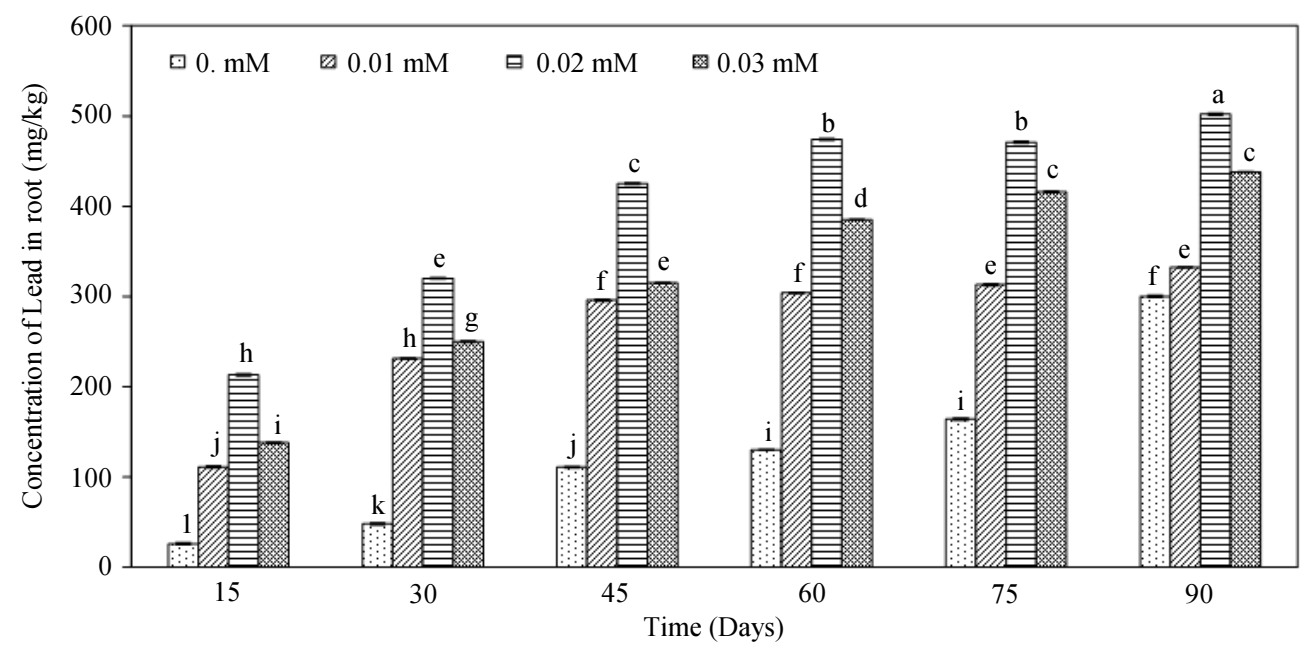

(c)

Fig. 2: Pb uptake in the various parts of C. esculenta (a) Leaves (b) Petioleand (c) Roots 
This is different from the distribution of $\mathrm{Pb}$ fractions measured upstream and downstream within the polluted area, i.e. reducible fraction was the major component found upstream, whereas strongly dissociated fractions (oxidizable and residual) were the major components found in the downstream samples.

\section{Pb Uptake in Plant Leaves}

The results in Fig. 2a show that amount of $\mathrm{Pb}$ absorbed in $C$. esculenta leaves was very small for all sets of treatments at 15 days to the time of harvest, which were $3.35,4.91,4.94$ and $4.93 \mathrm{mg} \mathrm{kg}^{-1}$, respectively for $\mathrm{Pb}$ dose at $0,0.01,0.02$ and $0.03 \mathrm{mM}$. This study shows the $\mathrm{Pb}$ accumulation in $C$. esculentaplant increased as the harvested time increased over the overall time period. The $\mathrm{Pb}$ set of $0.03 \mathrm{mM}$ had the highest uptake rate of $91.06 \mathrm{mg} \mathrm{kg}^{-1}$ at 90 days. All sets showed a significant difference with the other treatments $(p<0.05)$. The results indicated that treatment of $\mathrm{Pb}$ with EDTA absorbed higher amounts than treatment of $\mathrm{Pb}$ without EDTA at all times of harvesting. From the statistical analysis, it was shown that there was a significant difference between treatments $(p<0.05)$. This was because of the addition of EDTA in the water, which affected the $\mathrm{Pb}$ translocation and accumulation in plants. Consistent with this, Liphadzi et al. (2003) studied EDTA assisted heavy metal uptake by using sunflowers when EDTA concentrations were 0, 0.5, 1 and 2 grams per kilogram $\left(\mathrm{g} \mathrm{kg}^{-1}\right)$ in soil. They found that the sunflower was able to absorb and accumulate heavy metal in the leaves, with accumulation rates increasing when more EDTA was added. The concentration of EDTA affected the heavy metal uptake of the plant study. These results found that the concentration of EDTA at $0,0.5$ and 1 gram per kilogram $\left(\mathrm{g} \mathrm{kg}^{-1}\right)$ had the absorbed a higher rate of heavy metals in the leaves as the concentration of EDTA increased. However, the leaves of the sunflowers absorbed less heavy metal when the concentration of EDTA increases at $2 \mathrm{~g} \mathrm{~kg}$. . Moreover, Li et al. (2008) found that Typhaorientalis absorbed $\mathrm{Pb}$ at concentrations of EDTA at $0.1 \mathrm{mM} \mathrm{L}^{-1}$ which was higher than the concentration of EDTA at $0.5 \mathrm{mM} \mathrm{L}^{-1}$.

\section{Pb Uptake in Plant Petioles}

The results show that the petiole sections of $C$. esculenta absorbed $\mathrm{Pb}$ only very slightly at the harvesting time of 15 days. For the experimental sets: (1) with $\mathrm{Pb}$ but without EDTA, (2) with $\mathrm{Pb}$ and EDTA 0.01 $\mathrm{mM} \mathrm{L}^{-1}(3)$ with $\mathrm{Pb}$ and EDTA $0.02 \mathrm{mM} \mathrm{L}^{-1}$ and (4) with $\mathrm{Pb}$ and EDTA $0.03 \mathrm{mM} \mathrm{L}^{-1}$ (Fig. 2b) Pb uptake was at $4.78,4.95,5.51$ and $4.98 \mathrm{mg} \mathrm{kg}^{-1}$, respectively. The $C$. esculenta absorption had the highest trend of increase as the harvest time increased. Thus, the uptake by $C$. esculenta was highest with the set of $\mathrm{Pb}$ and EDTA 0.03 $\mathrm{mM} \mathrm{L}^{-1}$ at day $90,126.19 \mathrm{mg} \mathrm{kg}^{-1}$. From the statistical analysis, it is shown that there were significant differences between treatments $(p<0.05)$. The comparison of $\mathrm{Pb}$ treatment with and without EDTA sets; the result indicated that the treatment of $\mathrm{Pb}$ and EDTA absorbed at higher rates than treatment of $\mathrm{Pb}$ without EDTA during the harvesting times. These were significant differences between treatments $(p<0.05)$. Moreover, treatment of $\mathrm{Pb}$ and EDTA $0.02 \mathrm{mM} \mathrm{L}^{-1}$ accumulated $\mathrm{Pb}$ at a higher rate than treatment of $\mathrm{Pb}$ without EDTA and such rate was 1.9 fold. This might be due to the ability of EDTA to combine $\mathrm{Pb}$ in the form useful to plants. As a result, the plant exhibited an ability to absorb $\mathrm{Pb}$ even more. This is consistent with Epstein et al. (1999)'s study of Brassica juncea grown in $\mathrm{Pb}$ contaminated soilwith the addition of EDTA concentrations of $0,1,5$ and $10 \mathrm{mM} \mathrm{kg}^{-1}$ in soil. The results showed that Brassica juncea was able to accumulate $\mathrm{Pb}$ in the petiole section, whereby $\mathrm{Pb}$ increased in line with increasing EDTA concentrations of 0,1 and $5 \mathrm{mM} \mathrm{kg}^{-1}$ and the $\mathrm{Pb}$ decreased at a concentration of EDTA $10 \mathrm{mM} \mathrm{kg}^{-1}$. This result can also be related to Ebrahimi(2014), which found that the addition of EDTA can have positive effects on $\mathrm{Pb}$ and $\mathrm{Cr}$ uptake when using Echinochloa crus-galli (L) Beauv.

\section{Pb Uptake in Plant Roots}

The results show that the $C$. esculenta's roots absorbed $\mathrm{Pb}$ very slightly in all of sets or treatments at 15 days of harvesting time, which were recorded as $26.33,111.96,215.52$ and $138.77 \mathrm{mg} \mathrm{kg}^{-1}$, respectively at treatment (1) with $\mathrm{Pb}$ but without EDTA, (2) with $\mathrm{Pb}$ and EDTA $0.01 \mathrm{mM} \mathrm{L}^{-1}(3)$ with $\mathrm{Pb}$ and EDTA $0.02 \mathrm{mM} \mathrm{L}^{-1}$ and (4) with $\mathrm{Pb}$ and EDTA $0.03 \mathrm{mM} \mathrm{L}^{-1}$ (Fig. 2c). The harvesting time at 90 days shows that the treatment with $\mathrm{Pb}$ solution added with EDTA $0.02 \mathrm{mM} \mathrm{L}^{-1}$ exhibited the highest uptake of $\mathrm{Pb}$ into $C$. esculenta's roots at 502.84 $\mathrm{mg} \mathrm{kg}{ }^{-1}$ which was higher than all of treatments and were $1.67,1.51$ and 1.15 fold, respectively. These were significant differences between treatments $(p<0.05)$. These results also related with Hegazy et al. (2011) found that the $\mathrm{Pb}$ accumulation was higher in roots than the other parts of plants. These findings are similar to those reported by Abrantes et al. (2007), who found the direct effect of a chelating agent on $\mathrm{Cd}$ accumulation in Halimioneportulacoides, especially in the roots (Sampanpanish and Tantitheerasak (2015). Consistent with the research of Duo et al. (2010) who studied how grass (Turf) absorbs heavy metals when adding EDTA at a dose of $0,10,15,20,25$ and $30 \mathrm{mM} \mathrm{kg}^{-1}$. The results showed that the Turf grass absorbed heavy metals, with the trend of absorption increasing when the concentration of EDTA increased. The highest level of heavy metals absorbed was at the EDTA dose of $20 \mathrm{mM} \mathrm{kg}^{-1}$. Turf 
grass showed the heavy metal uptake trend to decrease at an EDTA dose of 25 and $30 \mathrm{mM} \mathrm{kg}$. Grcman et al. (2001) studied the absorption of $\mathrm{Pb}$ with Brassica rapa by adding EDTA at 3,5 and $10 \mathrm{mM} \mathrm{kg}^{-1}$ in soil. They found that with the concentrations of EDTA at 3 and 5 $\mathrm{mM} \mathrm{kg}$, Brassica rapa absorption and accumulation of $\mathrm{Pb}$ in the root increased when the concentration of EDTA increased. But Brassica rapa absorption of $\mathrm{Pb}$ also showed a trend of decrease at a concentration of EDTA $10 \mathrm{mM}$ $\mathrm{kg}^{-1}$. Moreover, Khamla and Sampanpanish (2015) showed that arsenic (As) accumulation in roots was significantly higher than in stems and leaves $(p<0.05)$ and was maximal after 120 days of cultivation, at which point the As concentration reached $29.71 \mathrm{mg} \mathrm{As} / \mathrm{kg}$ in the roots compared to $6.32 \mathrm{mg} \mathrm{As} / \mathrm{kg}$ in the stem and leaves. The average Asaccumulation in all parts of the plant over four months was 2.71-36.03 mg As/kg per plant.
Effects of $\mathrm{Pb}$ and EDTA on Phytotoxicity of $C$. esculenta

The phytotoxicity during the time period over 90 days of the experiment shows that $C$. esculenta did not have exhibit toxicity symptoms in the treatment process with $\mathrm{Pb}$ but without EDTA, with $\mathrm{Pb}$ and EDTA $0.01 \mathrm{mM}$ $\mathrm{L}^{-1}$ and treatment of $\mathrm{Pb}$ and EDTA $0.02 \mathrm{mM} \mathrm{L}^{-1}$. Note that, $C$. esculenta exhibited toxicity in the treatment of $\mathrm{Pb}$ and EDTA $0.03 \mathrm{mM} \mathrm{L}{ }^{-1}$. Phytotoxicity (Fig. 3) symptoms included, for example, wilting leaves, curling leaves, yellow color appearing in leaf margins and plants eventually dying (Akkajit, 2015). Moreover, Pb might be able to interfere with and resist the process of photosynthesis by absorbing nutrients into plants.

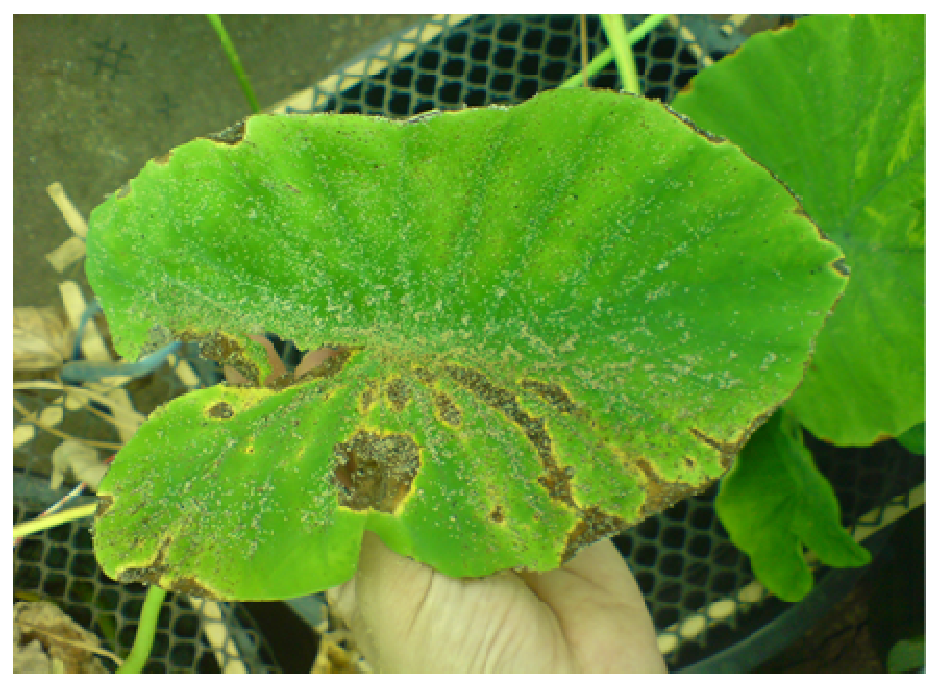

(a)

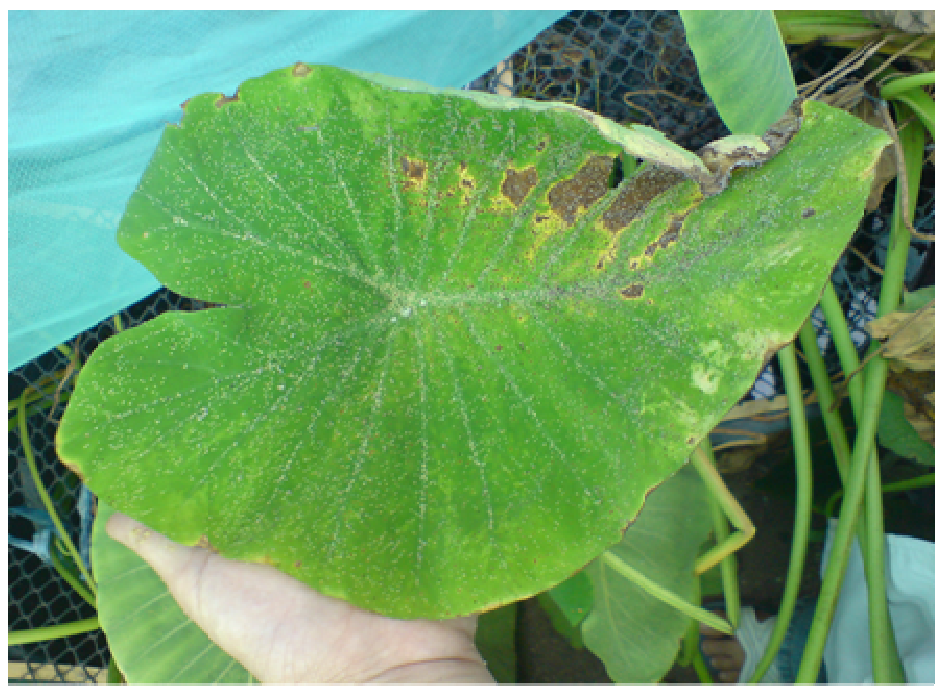

(b)

Fig. 3: (a) Yellow leaf margins, and (b) wilting and curling leaf 
The significantly lower phytotoxicity between EDTA $0.03 \mathrm{mM} \mathrm{L}^{-1}$ compared with EDTA $0.02 \mathrm{mM} \mathrm{L}^{-1}$ in $\mathrm{Pb}$ solution also relates with $\mathrm{Wu}$ et al. (2004), who used Chinese mustard (Brassica juncea) with EDTA to remediate the heavy metal. The results showed that EDTA potentially reduced the phytotoxicity of heavy metal to Chinese mustard and also enhanced the cadmium accumulation. This finding also agreed well with the effects of $\mathrm{Cd} \mathrm{Zn} \mathrm{Pb}$ and $\mathrm{Cr}$ uptake with Arum (Colocasiaesculenta L.); Grass (Kochiascoparia) phytotoxicity and growth reported by Islam et al. (2017) and Zhao et al. (2015).

\section{Conclusion}

This study reproduced the effects of $\mathrm{Pb}$ removal in contaminated water using EDTA by $C$. esculenta. The results showed that plants exhibited an increase in $\mathrm{Pb}$ uptake in trend with an increase of time. C. esculenta was grown well in contamination water with different sets of $\mathrm{Pb}$ and EDTA. The set with $\mathrm{Pb}$ and EDTA showed the highest potential uptake of $\mathrm{Pb}$ compared to the set with $\mathrm{Pb}$ and without EDTA. Moreover, $C$. esculenta showed a trend of absorbing more $\mathrm{Pb}$ when the dose of EDTA increased. The treatment with $\mathrm{Pb}$ and EDTA at $0.03 \mathrm{mM} \mathrm{L}^{-1}$ showed a trend of decreasing $\mathrm{Pb}$ absorption and showed toxicity on the leaves of $C$. esculenta. The phytotoxicity symptoms were also exhibited, such as wilting leaves, curling leaves, yellow color appearing in the leaf margins and plants dying. Thus, it can be concluded that C. esculenta can be useful for the monitoring and cleanup of $\mathrm{Pb}$ from $\mathrm{Pb}$ contaminated water and soil. It is worth considering that any following research should focus the types of plants that have a higher $\mathrm{Pb}$ uptake potential than this the $C$. esculenta plant used in this research. Such plant species should also be hyperaccumulators, non-edible and able to be used as alternative energy such as Jatrophacurcas, Meliosmapinnata, Leucaenaleucocephala andEucalyptus camaldulensis. Especially, PennisetumpurpureumSchum cv. Mott (Napier grass) can be utilized as a biomass for producing heat and electricity.

\section{Acknowledgement}

The authors thank the Office of Higher Education Commission (OHEC) and the S\&T Postgraduate Education and Research Development Office (PERDO) for the financial support of the Research Program and thanks the Ratchadaphiseksomphot Endowment Fund, Chulalongkorn University for the Research Unit. We would like to express our sincere thanks to the Environmental Research Institute, Chulalongkorn University (ERIC) and the Center of Excellence on Hazardous Substance Management (HSM), for their invaluable supports in terms of facilities and scientific equipment.

\section{Author's Contributions}

This article is original research paper. Authors participated in all experiments, coordinated the data analysis and contributed to the written and read of this manuscript. Authors give final approval of the version to be submitted this journal.

\section{Ethics}

The authors declare no conflicts of interest and confirm that the manuscript has been submitted solely to this journal and is not published, in press, or submitted elsewhere.

\section{References}

Abrantes, S., M.E. Amaral, A.P. Costa and A.P. Duarte, 2007. Hydrogen peroxide bleaching of Arundodonax L. kraft-anthraquinone pulp-effect of a chelating stage. Industrial Crops Products, 25: 288-293. DOI: 10.1016/j.indcrop.2006.12. 006

Aisien, F.A., I.O. Oboh and E.T. Aisien, 2012. Phytotechnology-Remediation of Inorganic Contaminants. In: Phytotechnologies, Anjum, N.A., M.E. Pereira, I. Ahmad, A.C. Duarte and S. Umar (Eds.), CRC Press, pp: 75-82.

Akkajit, P., 2015. Review of the current situation of Cd contamination in agricultural field in the Mae Sot district, Tak province, northwestern Thailand. Applied Environ. Res., 37: 71-82.

DOI: $10.14456 /$ aer.2015.9

Aransiola, S.A., U.J.J. Ijah and A.P. Abioye, 2013. Phytoremediation of lead polluted soil by Glycine max L. Applied Environ. Soil Sci., 1: 1-7. DOI: 10.115 5/2013/631619

Chen, S., T.H. Sun, L.N. Sun, Q.X. Zhou and L. Chao, 2006. Influences of phosphate nutritional level on the phytoavailability and speciation distribution of cadmium and lead in soil. J. Environ. Sci., 18: 1247-1253. DOI: 10.1016/S1001-0742(06)60070-3

Chiyapreuk, S., 1993. Abundance of the soil. Department of Soil Science, Faculty of Agriculture, Kasetsart University, Bangkok, Thailand.

Cho, Y., J.A. Bolick and D.J. Butcher, 2008. Phytoremediation of lead with green onions (Allium fistulosum) and uptake of arsenic compounds by moonlight ferns (Pteriscreticacv Mayii). Microchemical J., 91: 6-8.

DOI: $10.1016 /$ j.microc.2008.05.008

Dumbrava, A., S. Birghila and M. Munteanu, 2015. Contributions on enhancing the copper uptake by using natural chelators, with applications in soil phytoremediation. Int. J. Environ. Sci. Technol., 13: 929-938. DOI: $10.1007 / \mathrm{s} 13762-013-0467-\mathrm{x}$

Duo, L.A., F. Lian and S.L. Zhao, 2010. Enhanced uptake of heavy metals in municipal solid waste compost by turfgrassfolloeing the application of EDTA. Environ. Monitoring Assessment, 165: 377-387. DOI: 10.1007/s10661-009-0953-2 
Ebrahimi, M., 2014. The Effect of EDTA Addition on the Phytoremediation Efficiency of $\mathrm{Pb}$ and $\mathrm{Cr}$ by Echinochloa crus galii (L.) Beave and associated potential leaching risk. Soil Sediment Contamination: An Int. J., 23: 245-256. DOI: $10.1080 / 15320383.2014 .815153$

Epstein, A.L., C.D. Gussman, M.J. Blaylock, U. Yermiyahu and J.W. Huang et al., 1999. EDTA and $\mathrm{Pb}$-EDTA accumulation in Brassica Juncea grown in Pb-amended soil. Plant Soil, 208: 87-94.

Grcman, H., S. Velikonja-Bolta, D. Vodnik, B. Kos and D. Lestan, 2001. EDTA enhanced heavy metal phytoextraction: Metal accumulation, leaching and toxicity. Plant Soil, 235: 105-114.

Hegazy, A.K., N.T. Abdel-Ghani and G.A. El-Chaghaby, 2011. Phytoremediation of industrial wastewater potentiality by Typhadomingensis. Int. J. Environ. Sci. Technol., 8: 639-648.

Islam, S.M., M.A. Kashem and K.T. Osman, 2017. Phytoextraction efficiency of cadmium and zinc by arum (Colocasiaesculenta L.) grown in hydroponics. Environ. Control Biology, 55: 113-119.

DOI: $10.2525 /$ ecb.54.113

Khamla, N. and S. Pantawat, 2015. Effect of NTA and EDTA on arsenic uptake from contaminated soil by Mimosa Pudica. Modern Applied Sci., 9: 280-291. DOI:10.5539/mas.v9n9p280

Li, L.Y., Y.G. Liu, J.L. Lui, G.M. Zeng and X. Li, 2008. Effects of EDTA on lead uptake by Typhaorientalispresl: A new lead-accumulating species in Southern China. Bulletin Environ. Contamination Toxicol., 81: 36-41. DOI: $10.1007 / \mathrm{s} 00128-008-9447-0$

Liphadzi, M.S., M.B. Kirkham, K.R. Mankin and G.M. Paulsen, 2003. EDTA-assisted heavy-metal uptake by poplar and sunflower grown at a long-term sewage-sludge farm. Plant Soil., 257: 171-182.

Phenrat, T., A. Otwong, A. Chantharit and G.V. Lowry, 2016. Ten year monitored natural recovery of lead contaminated mine tailing in Klity Creek, Kanchanaburi Province, Thailand. Environ Health Perspect., 124: 1511-1520. DOI: 10.1289/EHP215

Poopa, T., P. Pavasant, V. Kanokkantapong and B. Panyapinyopol, 2015. Fractionation and Mobility of Lead in Klity Creek Riverbank Sediments, Kanchanaburi, Thailand. Applied Environ. Res., 37: 1-10. DOI:10.14456/aer.2015.4

Sampanpanish, P. and N. Tantitheerasak, 2015. Effect of EDTA on Cadmium and Zinc Uptake by sugarcane grown in contaminated soil. Am. J. Environ. Sci., 11: 167-174. DOI: 10.3844/ajessp.2015.167.174
Sampanpanish, P., 2015. Phytoremediation. Bangkok: Chulalongkorn University, Bangkok, Thailand. pp: 232.

Sampanpanish, P., W. Pongsapich, S. Khaodhiar and E. Khan, 2006. Chromium removal from soil by phytoremediation with weed plant species in Thailand. Water, Air, Soil Pollution, 6: 191-206. DOI: $10.1007 / \mathrm{s} 11267-005-9006-1$

Tambamroong, W., 2002. Phytoextraction of arsenic from contaminated soil by Colocasiaesculenta (L.) Schott; Taro and Wild taro. Master's Thesis, Department of Environmental Science, Graduate School, Chulalongkorn University. Bangkok, Thailand.

Tananonchai, A. and P. Sampanpanish, 2014. Effect of EDTA and DTPA on cadmium removal from contaminated soil with water hyacinth. Applied Environ. Res., 36: 65-76.

DOI: $10.14456 /$ aer.2014.25

Tang, Y.T., R.L. Qiu, X.W. Zeng, R.R. Ying and F.M. $\mathrm{Yu}$ et al., 2008. Lead, zinc, cadmium hyperaccumulation and growth stimulation in ArabispaniculataFranch. Environ. Experimental Botany, 66: 126-134.

DOI: 10.1016/j.envexpbot.2008.12.016

Tanhan, P., 2008. Phytoextraction of lead Chromolaenaodorata: Hydroponic and experimaents. The degree doctor of philosophy (biology) faculty of graduate studies Mahidol University, Bangkok.

USEPA, 1996. Microwave assisted acid digestion of siliceous and organically based matrices. Method. 3052, Washington D.C., USA.

USEPA, 1998. Microwave assisted acid digestion of aqueous samples and extracts. Method. 3015A, Washington D.C., USA.

USEPA, 1998a. Integrated Risk Information System (IRIS). Online, National Center for Environmental Assessment, Cincinnati, $\mathrm{OH}$.

USEPA, 1998b. A citizen's guide to phytoremediation. Office of Solid Waste and Emergency Response. Washington D.C., USA.

USEPA, 1999. Phytoremediation resource guide. Office of Solid Waste and Emergency Response. Washington D.C., USA.

Wu, L.H., Y.M. Luo, X.R. Xing and P. Christie, 2004. EDTA-Enhanced phytoremediation of heavy metal contaminated soil with Indianmastard and associated potential leaching risk. Agriculture Ecosystem Environ., 102: 307-318.

DOI: $10.1016 /$ j.agee.2003 09.002

Zhao, S.L., X.J. Shang and L.A. Duo, 2015. Effects of ethylenediaminetetraacetic acid and ammonium sulfate on $\mathrm{Pb}$ and $\mathrm{Cr}$ distribution in Kochiascoparia from compost. Int. J. Environ. Sci. Technol., 12: 563-570. DOI: 10.1007/s13762-013-0426-6 